\title{
Postscript and conclusion
}

In 1911, King George V was the first and last reigning British monarch to visit Britain's Indian Empire. His coronation durbar in Delhi represented both the political and cultural pinnacle of the ritual apparatus developed during the second half of the nineteenth century, but also the ways in which it was unravelling in the years before the First World War. It also demonstrated how imperial culture was made by complex modes of reception and appropriation, how ideas about empire, citizenship, and identity were forged in encounters and experiences 'on the ground', as it were, and how colonial knowledge was always imperfect and partial.

The Delhi durbar was the greatest act in the performance of imperial culture by British royals. The royal jeweller crafted a lighter model of the imperial crown, costing the Indian treasury $£ 60,000$, for the long durbar on a hot Delhi day. ${ }^{1}$ Sir Philip Gibbs, the biographer of George V, described the scene at the durbar as 'the most brilliant, the most imposing, the most gorgeous State Ceremony the world has ever known'. ${ }^{2}$ The ritual also marked the transfer of the imperial capital from Calcutta to Delhi, a former centre of Mughal power. During one part of the ceremonies, the King and Queen 'sat on the marble balcony ... showing themselves to the [thousands of] people' at Delhi Fort, the palace of the Mughal Emperor Shah Jahan, in a ceremony proposed by the King himself. ${ }^{3}$ The 1911 Delhi durbar was one of the grandest ritual performances in the history of the British Empire, a culmination of the royal tours and the British ornamental imagination.

The ritual practices of the royal tour were on full display in Delhi. George V received and gave addresses. The viceroy gave and received visits with the princely elite, and the King granted private audiences to the more important princes. Massive tents were erected to serve as residences for visiting dignitaries. Like his uncle, Prince Alfred, the King went tiger hunting in the Nepal forests. ${ }^{4} \mathrm{He}$ inspected imperial 
troops and the living veterans of the Indian Mutiny. ${ }^{5}$ Curiously, the great controversy of the durbar involved a familiar character, and his alleged disrespect toward the King-Emperor:

No incident of the Coronation Durbar at Delhi aroused more interest than did the manner in which the Gaekwad of Baroda played homage. The cinematograph films show that, when coming to perform this, he was swinging a stick in his hand, which to say the least of it, was decidedly unusual, and that, having bowed curtly and retreated a pace or two, he turned his back on the King-Emperor and walked off, instead of leaving the Presence backwards as did others doing homage. Considerable comment having been caused by this, the Viceroy, with his Highness's consent, published a letter in which the Gaekwad assures Lord Hardinge of his loyalty and allegiance to the throne, sets down his failure to observe strict etiquette to nervous confusion in the presence of their Majesties before the great assembly, says that, being second of the Feudatory Princes and failing to see exactly what the Nizam of Hyderabad did, had no chance of observing the others do homage. ${ }^{6}$

The Gaekwad of Baroda was Sayaji Rao III, the young prince whom the Prince of Wales had met in 1875 . He had recently converted to a liberal nationalism, making contributions to the Indian National Congress and Dadabhai Naoroji's British parliamentary campaign. ${ }^{7}$ As a result, he had been carefully monitored by the British Resident in Baroda. While there is no evidence that the gaekwad purposely snubbed the King, his political sympathies, which transcended the difference between 'traditional' and 'modern' politics, certainly make one wonder. Ritual contestation, after all, had a long tradition in the encounters between British royals and local people.

The coronation durbar represented more than the far reaches of the British ritual imagination. It was a calculated response to the development of a more radical and separatist Indian nationalism during the first decade of the twentieth century. In 1906, the INC split into factions: the Garam Dal, the radicals led by Bal Gangadhar Tilak, and Naram Dal, the loyalist 'Moderates' under Gopal Krishna Gokhale. On one hand, the 1905 partition of Bengal - a British tactic of divide and conquer - unleashed a firestorm of political contestation from Bengali nationalists. On the other hand, the Indian Councils Act of 1909, the Morley-Minto reforms, instituted political reforms that allowed Indians to be elected to local and provincial councils for the first time, a concession that failed to appease an increasingly mass nationalist movement. In 1911, the visit of George V was used as an opportunity to counter the propaganda of Indian nationalism. The King announced the reunification of Bengal, bonuses for military and civilian servants of the government, and grants for educational advancement. ${ }^{8}$ 


\section{POSTSCRIPT AND CONCLUSION}

The durbar invoked the mythology of the patriot king, the Great (White) King who loved and protected his subjects. While the British monarch had long been an object of petitions and demands - to make right the wrongs of other British subjects or governments - this mythology was most carefully and successfully crafted and nurtured during the long reign of Queen Victoria. George V, and the monarchs who followed him, exploited the ritual and ideological apparatus of the nineteenth-century empire to legitimise and justify the monarchy and the empire well into the twentieth century. At the same time, as the coronation durbar demonstrates, these ritual practices, which were limited and unstable from their inception, were increasingly undermined, delegitimised, and challenged by emerging mythologies of belonging and identity politics.

Royal tourists, colonial subjects and the making of a British world has reflected on a diverse cast of characters, culled from different historical sites and representative of different discourses of British imperial culture: a Great Queen dispossessed of the power to control her own image; royal children bored with the tedium of their royal ambassadorships; African chiefs, Indian princes, and a Maori King who participated in or contested the mythology of the Great Queen; colonial governors who used the visits as opportunities to impress and defeat Britain's enemies; Western-educated respectables who used an idiom of British constitutionalism to demand imperial citizenship; colonial settlers who claimed to be 'better Britons'; and loyalist Dutch-speaking South Africans and an Irish assassin who envisioned a future for the Irish in the empire. These examples demonstrate the ways in which imperial culture was made, not at Windsor Castle, or in the halls of the Colonial Office, or in Government House in Calcutta or Cape Town or Auckland, but by human actors in the empire, who made sense of their political, cultural, and social worlds the best they could and with the tools that they had as subjects of a global empire. These encounters demonstrate how imperial culture, fragile and unstable, uncontainable and uncontrollable, was made in the empire.

The First World War has been identified by scholars as a transformative moment in the history of Britain and the British Empire. The war was a breaking point for many 'loyalist' people of colour in Britain's African and Indian empires, who became increasingly disillusioned by the broken promises of imperial service and citizenship during and in the aftermath the war. ${ }^{9}$ In India, British soldiers opened fire on civilians protesting against the Rowlatt Act, an extension of the oppressive wartime 'emergency measures', in the Amritsar Massacre (1919), which 
proved to be a turning point for many Indian nationalists. The white colonies of settlement earned their spurs during the war, as reflected in the Balfour Declaration (1926) and the Statute of Westminster (1931), completing the long evolution from responsible government and home rule to independent Dominion status. In New Zealand and Australia, emerging national mythologies were forged in the blood of ANZAC troops in the trenches of Gallipoli. In the aftermath of the war, however, Britain became more and more dependent on the empire for trade and the maintenance of its global power in a changing world order, symbolised by the Covenant of the League of Nations as well as the financial and political rise of the United States.

The political and cultural wind of change, to borrow Harold Macmillan's 1960 turn of phrase, was already blowing through the empire, however. The changes attributed to the war represented significant continuity with the previous decades rather than a radical break with the past. The development of home rule, designed to avoid another imperial disaster like the American and Canadian revolts, and settler disputes with the imperial government had nurtured these changes for the last half-century. In South Africa, respectables of African and Coloured descent were profoundly disillusioned by the failure of the imperial government to intervene against the disenfranchisement of the Union of South Africa (1910) or the dispossession of the Native Lands' Act (1913). In India, the British failed to live up to the promises of the war, encouraging the growth of the mass anti-nationalist movement that had rapidly developed in the decade before the war. The changing politics of Sol Plaatje and Mohandas Gandhi, from imperial citizenship to non-cooperation and contestation, reflect the changing nature of imperial politics for local peoples.

The second half of the nineteenth century was a transitional period in the history of the British Empire, when notions of imperial identity and citizenship came to dominate (however briefly) the cultural and political landscape of imperial culture. This is not to say that local and nationalist identities were not forged, but that they did so in the milieu of imperial politics. By and large, Queen Victoria's English-speaking subjects imagined their political and cultural universes with an inward gaze toward their local communities and an outward gaze toward Britain and the empire. The politics of this era were, overwhelmingly, not separatist or anti-imperial, nationalist in a twentieth-century sense, but embraced Britishness and imperial citizenship, the rights and responsibilities of citizen-subjects of the Queen and the co-ownership of a global empire. While these ideas manifested themselves in diverse and often conflicting ways, they informed the lives of 'overseas Britons', many of whom had no ethnic or racial claim to Britishness, and made 


\section{POSTSCRIPT AND CONCLUSION}

an imperial culture that could not be dictated from Britain, from colonial capitals, or by local social elites. During the twentieth century, they would re-emerge in the demands of Second World War veterans, the claims of the Windrush generation, and British Muslims in the aftermath of the $7 / 7$ bombings.

In Britain, the revived public consciousness of the empire resulted from the experiences of the war and anxieties about Britain's future as a world power. Between 1903 and the war, for instance, the Tariff Reform League advocated for Imperial Preference, a protectionist zone designed to counter the growing industrial power of the United States and Germany. ${ }^{10}$ While the British Empire was at its greatest geographical extent in the aftermath of the war, it was an empire in decline. At the same time, British society was becoming a mass, democratic society - symbolised by the abolition of the House of Lords' legislative veto power (1911), the enfranchisement of women over thirty (1919), and the development of a modern mass media.

As David Cannadine has argued, these transformations made the monarchy a greater novelty, with Buckingham Palace becoming a tourist trap rather than a centre of power, and royal memorabilia, which became popular during the Golden and Diamond Jubilees, transforming a 'sacred' monarchy into a consumer fetish. The development of radio and film made the monarchy more accessible - in some sense making the royal tour obsolete - but during an era when the imperial monarchy and its empire were both on the wane. ${ }^{11}$ Today, Elizabeth II may be a symbolic head of state for millions of people across the globe, but she lacks the symbolic influence of the Great Queen. ${ }^{12}$ Her people may adore her, but largely because she has no power over them and because they are not her subjects but citizens.

Recent works of the 'imperial turn' represent the imperial experience in a far more sophisticated analytic than their predecessors, often influenced by the important work of area studies scholars in the fields of African, South Asian, and Australasian history (who have as much of a claim on doing a history of empire as British scholars). British imperial history has likewise been influenced and reshaped by scholars of the former colonies of settlement, many of whom have embraced the notion of a British World. The dialectic of collaboration/resistance has been largely rejected and the role of imperial politics more seriously considered. The current work has been profoundly shaped by and (hopefully) contributes significantly to this scholarly milieu by offering a study of the unique encounter and experience offered by the royal tour of empire. It is a book about how the empire was imagined and experienced by different historical actors, representing unique discourses of imperial culture, across the space of the nineteenth-century 


\section{ROYAL TOURISTS}

British Empire. It importantly recentres the making of imperial culture, locating the empire itself in the centre of these processes, and offers for consideration - standing on the shoulders of several recent scholars - the centrality of Britishness and imperial citizenship to Queen Victoria's colonial subjects.

\section{Notes}

1 A. N. Wilson, After the Victorians: The Decline of Britain in the World (New York, 2005), 129.

2 Philip Gibbs, George the Faithful: The Life and Times of King George V (London, 1936), 212.

3 Illustrated London News, 6 January 1912.

4 The Times, 21 September 1911.

5 Illustrated London News, 6 January 1912.

6 Illustrated London News, 6 January 1912.

7 Lawrence James, Raj: The Making and Unmaking of British India (New York, 1997), 338.

8 Richard Burn, 'Political Movements, 1909-1917', in The Cambridge History of the British Empire, vol. 5, The Indian Empire, 1858-1918, ed. H. H. Dowell (Cambridge, 1932), 575-6.

9 Bill Nasson, 'Why They Fought: Black Cape Colonists and the Imperial Wars, 1899-1918', International Journal of African Historical Studies 37, no. 1 (2004): 55-70.

10 See Andrew Thompson, Imperial Britain: The Empire in British Politics, c. 1880-1932 (New York, 2002); David Thackeray, 'The Crisis of the Tariff Reform League and the Division of "Radical Conservatism", c. 1913-1922', History 91, no. 301 (2006): 45-61; E. H. H. Green, The Crisis of Conservatism: The Politics, Economics and Ideology of the Conservative Party, 1880-1914 (New York, 1996). Of course, the years of the tariff reform campaign represented a long time in the wilderness for the Conservatives, making one wonder how much the issue mattered to most voters.

11 The monarchy recovered some of its cultural significance during the Second World War, for instance, but experienced blows to its prestige during the Abdication Crisis (1936) and following the death of Princess Diana (1997). The tabloid press, an invention of the nineteenth century, also contributed to these processes of trivialisation.

12 Philip Murphy persuasively argues that she symbolises and personifies the Commonwealth. Monarchy and the End of Empire: The House of Windsor, the British Government, and the Postwar Commonwealth (Oxford, 2013). 